\title{
Preserve Urban Heritage District based on Place Identity
}

\author{
Nurlisa Ginting, N. Vinky Rahman \\ Department of Architecture, Faculty of Engineering, \\ University of Sumatera Utara, Indonesia \\ nurlisa.ginting@gmail.com
}

\begin{abstract}
The necessity to preserve architectural heritage of historical and cultural value is getting more necessary for maintaining place identity. Place identity indicates place uniqueness that is the attractiveness of heritage tourism. This research seeks to identify the preservation strategies in Maimoon Palace Heritage District, Medan City based on place identity. It contributes a better planning for Medan City in improving the quality of life. By employing mixed-methods, the result demonstrates that preservation should include both tangible and intangible elements. The elements of historic buildings, historical stories, nostalgia, and availability of additional element must be well-maintained to support the place identity.
\end{abstract}

Keywords: Preservation; place identity; Maimoon Palace heritage district; Medan City

eISSN 2514-751X (C) 2016 The Authors. Published for AMER ABRA by e-International Publishing House, Ltd., UK.. This is an open access article under the CC BY-NC-ND license (http://creativecommons.org/licenses/by-ncnd/4.0/). Peer-review under responsibility of AMER (Association of Malaysian Environment-Behaviour Researchers), ABRA (Association of Behavioural Researchers on Asians) and cE-Bs (Centre for EnvironmentBehaviour Studies), Faculty of Architecture, Planning \& Surveying, UniversitiTeknologi MARA, Malaysia. https://doi.org/10.21834/aje-bs.v1i1.145 


\subsection{Introduction}

Heritage indicates the reflection of the pattern and social behaviour of communities within entire society. It also takes an important role in creating character, image, and identity of urban (Pradjnawrdhi et al., 2015). It is a symbolic resource that is closely related to memory and identity (AbdelKader, 2011). Protecting heritage is an economical, historical, and cultural process (Ekwelem et al., 2011 in Hani et al., 2012).

In the line with the rapid globalization growth, heritage and tourism recently become inseparable combination that has been developed by many countries all over the world notably developing countries. By developing tourism, it can create civic pride, raise city profile, and attract investment as an attempt in improving the quality of life of residents and tourists as well (Wang and $\mathrm{Xu}, 2015$ ). In heritage tourism, place identity is the main attraction that distinguishes one place to others. Therefore, it is crucial for maintaining place identity. Preservation lately becomes the solution in maintaining the urban characteristic.

Through preservation, it can maintain the urban heritage district and the sense of place. It aims to encourage people to learn more about the history and culture of their predecessor, link to the continuity of past, present, and future, and also generate identity to an urban (Goodwin et al, 2009). Therefore, good strategies are urgently needed for the preservation of urban heritage district. Preserving urban heritage district needs appropriate planning to the urban characteristic. Therefore, preservation planning based on place identity is more crucial to attract a large number of tourists visit.

This paper seeks to identify the preservation strategies in Maimoon Palace, Medan City through the principles constructing place identity. It contributes a better planning for Medan City in improving the quality of life of residents and tourists.

\subsection{Literature Review}

Preservation can be interpreted as an effort to maintain the heritage elements, both tangible and intangible elements. The heritage preservation involves the preservation of physical heritages such as buildings, landscapes, structures, sites, and communities. Besides the tangible elements, preservation also encompasses the intangible elements, including oral tradition, music, and cultural activities (Coppin State University, 2002 in Hani et al., 2012).

Nowadays, people have big motivation in preserving heritage and history (Greffe, 2004 in Azhari and Mohamed, 2012). The awareness about losing heritage and local culture has emerged due to rapid of globalization growth. Hence, the effort of preservation becomes so significant in revitalizing the urban heritage district and keeping all memories (Said et al., 2013).

The preservation of historic buildings reflects not only the energy but also the spirit of people and identity of an urban district (Azhari and Mohamed, 2012). Therefore, preservation should be motivated by place identity and sense of place. 
Place identity has been widely discussed in many studies (e.g., White et al., 2008; Bernardo and Palma, 2005; Gospodini, 2002; Goodman, 2004; Lalli, 1992). One of place identity theory is Breakwell's theory (1986) which further developed by Twigger-Ross and Uzzel (1996). The theory identifies identity process seen as a dynamic social product of memory interaction (Wang and $\mathrm{Xu}, 2014$ ). It is constructed by four principles, i.e., distinctiveness, continuity, self-esteem, and self-efficacy.

The first principle of place identity is distinctiveness, indicates as desire to maintain a sense of personal distinctiveness that distinguishes from others. Meanwhile, continuity is a desire to preserve continuity of the self-concept. Its existence helps continuing, reshaping, and maintaining the place identity (Ginting and Wahid, 2015). Another principles is selfesteem, refers to a self-evaluation with which one identifies. Self-esteem is created by positive perception as a result of pride of a place. The last principle is self-efficacy, means as a belief in person's ability to work in physical environment and social situation (Twigger Ross \&Uzzell, 1996).

By maintaining place identity will obtain special feeling among tourists. It will be embedded in their minds through the local culture or the historic buildings that allow heritage tourism keeps growing continuously (Page and Lawton, 1999). The value can provide a distinctive experience to someone so the place will be recognizable easily (Yuen, 2005). Then, the place identity can support the quality of life and bring the happiness to the residents and tourists (Mohit, 2013). Since people live happy and healthy, they will give a contribution to the community (Sani and Mahasti, 2012).

\subsection{Methodology}

This research was conducted in Maimoon Palace Heritage District, Medan City. It is located on BrigjenKatamso St. and Singamangaraja St. which is the prime corridor of Medan City (Figure 1).

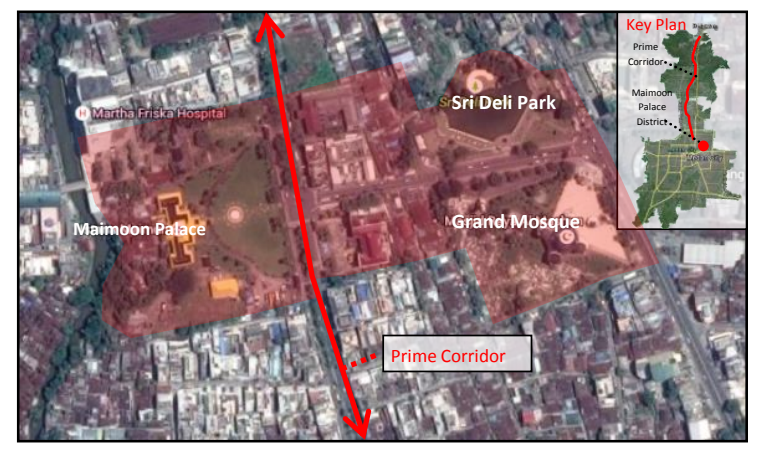

Figure 1: Maimoon Palace Heritage District

(Source: Google Earth, (2015)) 
Maimoon Palace Heritage District was selected due to well-known historical objects which is evidence of authority of Malay Deli kingdom in past, namely Maimoon Palace, Grand Mosque, and Sri Deli Park (Figure 2). Moreover, a prime corridor in a city always becomes heritage tourism component, especially to the historic corridor (Prideaux; Copper, 2002). Therefore, Maimoon Palace Heritage District should be well-planned to strengthen the characteristic of the area due to its potential of heritage tourism development.

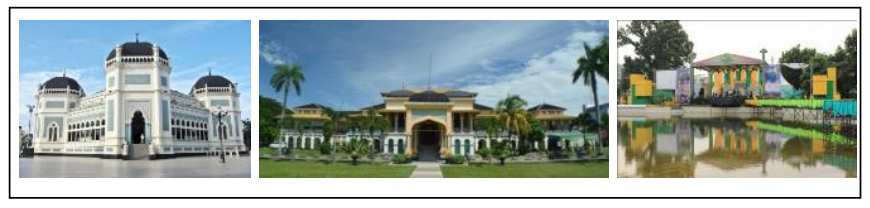

(a)

(b)

(c)

Figure 2: (a) Grand Mosque; (b) Maimoon Palace; (c) Sri Deli Park

(Source Author)

This research is series of research implemented in 2012 to 2014. In 2012, it identified the place identity of Maimoon Palace Heritage District through the four principles of place identity (i.e., distinctiveness, continuity, self-esteem, and self-efficacy) (Breakwell, 1986).

This research employed mixed-method to examine local people and tourists' perception of place identity. The qualitative method was implemented through field observation and depth interview with nine key respondents who play significant role in North Sumatera Tourism: tourism stakeholders; tourism expert; travels and hotels association; and the heritage buildings owners. Meanwhile, the quantitative method was conducted by distributing 360 questionnaires to 144 tourists (60\% domestic tourists: $40 \%$ foreign tourists) and 216 local people respectively. Then, all data were analyzed together to seek the principles of place identity.

In this research, the results of previous research (Ginting, 2014) are used to draw up spatial planning model of heritage tourism area based on place identity. Then, the current research combines the spatial planning elements with the place identity principles from the previous research. The spatial planning elements are obtained from the qualitative method through field observation, literature review, and depth interview result.

This planning includes the place identity principles in each planning elements through literature review and research of previous depth interview. Thus, this research will highlight any objects that go into preservation (Figure 3 ). 


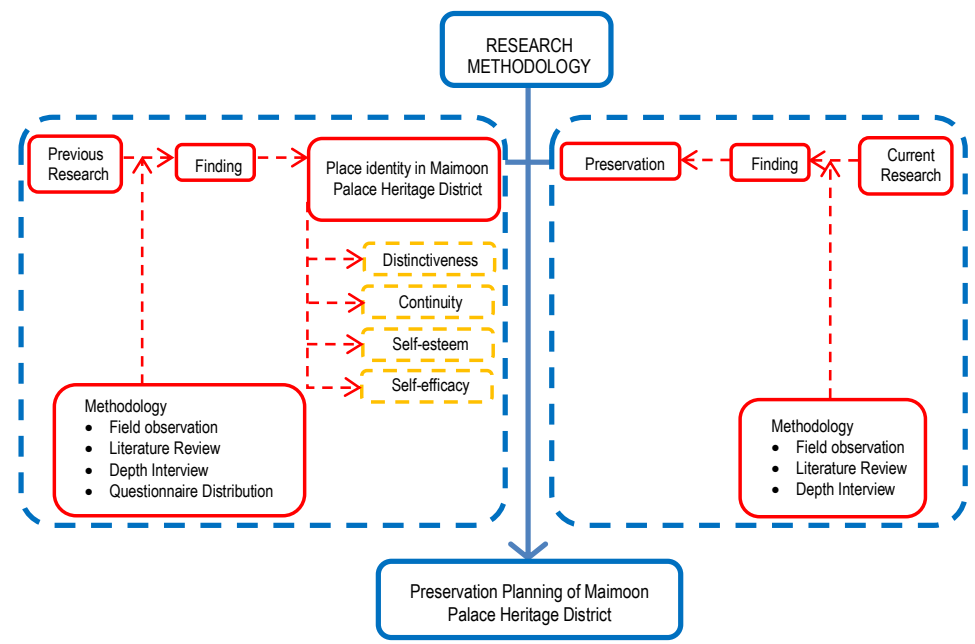

Figure 3: Flow Chart of Research Methodology

(Source: Author)

\subsection{Results and Discussion}

The previous research (Ginting, 2014) identified the four principles of place identity according to Breakwell theory (1986). It showed the elements which construct the principles of place identity (Table 1). The result of questionnaires which use SPSS version 20 and depth interview represent the four principles of place identity. Each principle consists of some elements where the local people and tourists would assess its condition. Their perception determined the assessment with a score of one to five based on Likert scale.

Table 1: Identity of Place in Research Area (Source: Author)

\begin{tabular}{|c|c|c|c|}
\hline \multicolumn{4}{|c|}{ Place Identity of Maimoon Palace Heritage District } \\
\hline Distinctiveness & Continuity & Self-esteem & Self-efficacy \\
\hline - Accessibility & $\begin{array}{l}\text { - Historic } \\
\text { buildings }\end{array}$ & - $\begin{array}{l}\text { Historic } \\
\text { buildings }\end{array}$ & - Signage \\
\hline - Historic buildings & $\begin{array}{l}\text { - Historical } \\
\text { stories }\end{array}$ & & $\begin{array}{l}\text { - Public } \\
\text { transportation }\end{array}$ \\
\hline - Local product & - Cultural activity & & - Parking area \\
\hline - Cultural product & $\begin{array}{l}\text { - Pedestrian } \\
\text { path }\end{array}$ & & - Pedestrian path \\
\hline & - Nostalgia & & - Bins \\
\hline & & & $\begin{array}{l}\text { - Public toilets } \\
\text { - Seating facilities }\end{array}$ \\
\hline
\end{tabular}


In this research, the principles of place identity take a role in drawing up the spatial planning, especially preservation. This paper highlights on preservation only, and ignores the other spatial planning elements according to Shirvani (1985), land use and function; building's style and physical size; circulation and parking; open space; pedestrian path; street furniture; activity in the area (Shirvani, 1985).

Moreover, not all the elements of the principles in previous research are included in preservation planning. Literature review and previous depth interview result determine the elements that should be included in preservation planning. Moreover, the literature review is used to explain more reasons in this preservation as well.

\subsection{Distinctiveness}

Previous research showed that in distinctiveness principle, respondents give positive perception of historic buildings (Ginting, 2014); Maimoon Place and Grand Mosque (Figure 2). Historic building contributes as the most favorable and attractive element due to its distinct characteristic. Besides the historic buildings, accessibilities, unique local product, and interesting cultural activity also receive positive the assessment from respondents as well.

The historic buildings which have high value of history will distinguish one place to others. In this research, the existence of Maimoon Place and Grand Mosque indicates landmark of Medan City.

Landmark influences the initial sign of people's imageability and memory of the city (Hussain and Ujang, 2014). Therefore, the existences of historic buildings in research area should be preserved in creating visitors' imageability and place identity to be considered in enhancing the future development of Maimoon Palace Heritage District. Moreover, it makes Maimoon Palace Heritage District more meaningful and memorable among tourists.

Although respondents give a positive assessment, the existences of historic buildings should be kept well-maintained as a preservation effort. Maimoon Palace heritage district condenses on Malay culture that can be seen through the esthetic values of Malay ornaments.

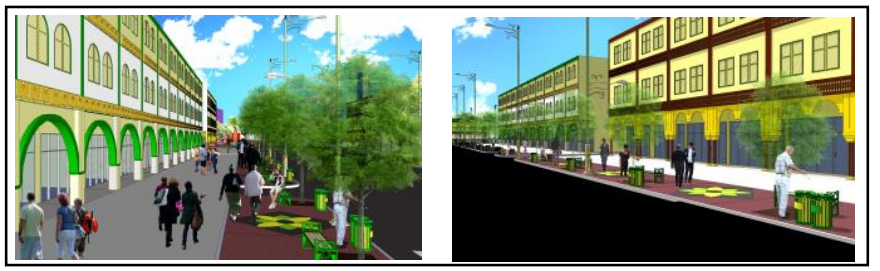

Figure 4: Malay Ornaments in Design of Building Facade and Street Furniture (Source: Author)

Malay ornament mostly draws symbolic values of plants. In preservation planning of Maimoon Palace heritage district, it can be applied to the design of building facade, 
signage, pavement, street furniture or any elements that represent Malay ambiance (Figure 4).

\subsection{Continuity}

To maintain the continuity in the research area, the elements that need to be preserved include historic buildings, historical stories, and nostalgia. Continuity includes three important elements, i.e., values, nostalgia or memories, and familiarity (Ginting and Wahid, 2015).

Based on previous research, value has a good assessment, proved that respondents have a positive perception of historic buildings, historical story, and cultural activity. They were interested in some well-maintained historic buildings due to the uniqueness. Moreover, they were amazed at the historical stories. The existence of cultural event held on also contributes the attractiveness of the heritage district.

Meanwhile, the nostalgia among tourists is low. In contrary, nostalgia is high among local people. They have distinctive experiences which flashback their memory in past. In preserving continuity, historic buildings should be well-maintained. Due to the physical damage of the historic buildings, the appropriate preservation effort is refurbishing the historic buildings to their original styles. The stakeholder should concern on the building performance and renovate the building physical quality.

Moreover, the historical stories in Maimoon Palace Heritage District are essential to be preserved as they create a recognizable landscape and increase the interest of the cultural heritage preservation (Knudsen \& Greer, 2008). The historical stories encourage positive assessment to the visitors in the area by forming its unique and continuous character. The historical story also gives information for visitors that is inseparable from the presence of historic buildings as it draws how historical buildings established.

Therefore, the existences of historical stories should be inherited to the next generation so the heritage tourism district would be well-known to the next generations and tourists as well. Historical stories can be preserved through presenting it on website or delivering to the traveler by tour guide managed by stakeholder.

Meanwhile, the preservation of nostalgia is closely related to the historic buildings and tradition in the area. The existences of the historical object as physical elements present special feeling to community. Local people are impressed with the memories of their childhood though tourists are less impressed. Therefore, nostalgia needs to be preserved.

\subsection{Self-esteem}

Self-esteem was built on the existences of historic buildings. Its existence is closely related to a sense of pride (Brown and Marshall, 2001). Someone prefers to live in a place that will create his/her pride due to the distinct characteristics of the places (Ujang\&Zakariya, 2015). Based on previous research, found that respondents are proud of having the historic buildings in research area as it has an important role in developing of Medan city and prove the past of Malay Kingdom Glory. They also have a sense of belonging. 
Based on depth interview with Deli Sultanate family and the head of Sumatera Utara Association of Travel Agency, respondents would be sad when a historic building was torn down and the existence of new buildings that are not contextual with surrounding environment. Consequently, the Maimoon Palace Heritage District may lose the characteristic of place.

The loss of historic buildings will make the sense of pride, belonging and bounded to the research area fade away. Moreover, it will cause the loss of identity. If a tourism area does not contain place identity and sense of belonging, then people will abandon the place in the end (Sani and Mahasti, 2012).

The sense of pride and belonging are some factors in creating people quality of life (Mohit, 2013). Therefore, self-esteem needs to be preserved due to the fulfillment people's needs.

Based on field observation, many information boards covered building façade cause negative perception. The information boards especially entertainment boards interfere view to the heritage buildings. Therefore, the location and size of the information board must be planned to keep the view of the heritage buildings.

\subsection{Self-efficacy}

The existence of efficacy in a tourism area is important as it is closely related to quality of life (Firouzmakan and Daneshpour, 2015). It directly connects to personal goal (Rampullo et al., 2015).

Based on previous research, the principle of self-efficacy is still low. Found that confidence gets positive assessment due to the existence of unique and typical landscapes. In a similar situation, accessibility receives good respond as well due to the sufficient public transportation.

Meanwhile, the additional elements such as pedestrian path, bins, public toilet, and seating facilities cannot support the people needs. Hence the comfort and safety have a negative assessment. Whereas, the additional element is one of the prime physical needs for people in doing their activity in forming the quality of life (Mohit, 2013).

In preserving self-efficacy, the additional elements should be provided to increase the satisfaction of both local people and tourists. The bins and seating facilities should be placed in certain range along the Maimoon Palace Heritage District (Figure 5).
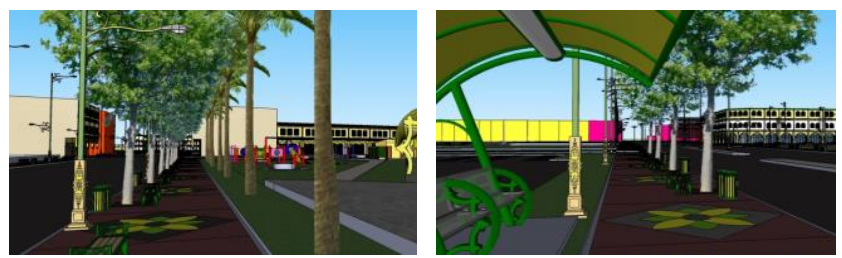

Figure 5: The Supporting Facilities in Research Area

(Source: Author) 
Moreover, Sri Deli Park needs to provide public toilets while Maimoon Palace and Grand Mosque need to increase the quality of existing toilets. The pedestrian path also should be provided and separated the access from car. Therefore, both local people and tourist feel the comfort and safety.

Based on findings of this research, preservation in Maimoon Palace Heritage District must cover the four principles of place identity (table 2). In maintaining distinctiveness and self-esteem, heritage buildings should be well-maintained, while the historical stories and nostalgia are needed to be preserved to support the continuity principles. Moreover, to keep self-efficacy, the additional elements are the focus of preservation.

Table 2: The Research Findings (Source: Author)

\begin{tabular}{lcll}
\hline \multicolumn{3}{c}{ Preservation of Maimoon Palace Heritage District } \\
\hline Distinctiveness & \multicolumn{1}{c}{ Continuity } & Self-esteem & Self-efficacy \\
\hline - Historic buildings & - Historic buildings & - Historic & - Signage \\
& buildings & \\
& - Historical stories & & - Pedestrian path \\
& & & - Bins \\
& & - Publalgia toilets \\
& & - Seating facilities
\end{tabular}

\section{Conclusion}

Preservation is closely related to place identity where place identity takes a significant role in forming place characteristic. Place identity is the main attraction in tourism development in gaining tourist satisfaction. Therefore, preservation should be planned based on place identity which includes tangible and intangible elements.

Based on the result, the preservation planning of Maimoon Palace Heritage District must include some elements of place identity principles; historic buildings, historical stories, nostalgia, and additional elements.

The result of this research could not apply directly due to unavailable of detail planning. Therefore, to complete the implementation, researcher suggests for the further research to make a detail of preservation planning. Moreover, the limitation in this research is the different result in each place due to the different behaviour and culture as well. A historical and cultural value in one place is not same in other places. Thus, the preservation effort cannot be implemented in other places. Hence, it needs preservation planning based on identity of the place. 


\section{Acknowledgement}

Authors greatly acknowledge the research funding from Research Institution of University of Sumatera Utara and the students of Architecture's Department, University of Sumatera Utara, Indonesia, for the contribution in this research.

\section{References}

AbdelKader, Behiri. (2011). Heritage Rehabilitation in Sustainable Development Policy for A Better Environment Quality in Small Historical Coastal Cities: The Case of Cherchell in Algeria. Procedia- Engineering, 21, 753-759.

Azhari, N. F. N., \& Mohamed, Embong. (2012). Public Perception: Heritage Building Conservation in Kuala Lumpur. Procedia-Social and Behavioral Science, 50, 271-279.

Brown, Jonathon D \& Marshall, Margaret A, 2001. Self-Esteem and Emotion: Some Thoughts About Feelings. Society for Personality and Social Psychology, 27, 575-584.

Firouzmakan, S., \&Daneshpour, S. A. (2015). Promotion Quality of Life by Increasing Place Attachment in Public Places. Procedia-Social and Behavioral Sciences, 201, 418-428.

Ginting, Nurlisa. (2014). Identititempatdanpengaruhnyaterhadappelanconganwarisan, kajiankes Bandar Medan Indonesia. USM Penang. (Unpublished Dissertation).

Ginting, Nurlisa\& Wahid, Julaihi. (2015). Exploring Identity's Aspect of Continuity of Urban Heritage Tourism. Procedia - Social and Behavioral Sciences. 202. 234- 241.

Goodwin, C., Ingham, J., \& Tonks, G. (2009). Identifying Heritage Value in URM buildings. Journal of the Structural Engineering Society New Zealand, Inc.

Hani, Ummu. et al. (2012). Preserving Cultural Heritage Through Creative Industry: A lesson from SaungAngklungUdjo. Procedia - Economics and Finance, 4, 193 - 200.

Hussain, Khairul Amin Mirsa and Ujang, Norsidah. (2014). Visitors' Identification of Landmarks in the Historic District of Banda Hilir, Melaka, Malaysia. Procedia - Social and Behavioral Sciences 153, 689 - 699.

Knudsen, Daniel C., \& Greer, Charles E. (2008). Heritage tourism, Heritage Landscapes and Wilderness Preservation: The Case of National Park Thy. Journal of Heritage Tourism, 3(1), 18-35.

Mohit, Mohammad Abdul. (2013). Quality of Life in Natural and Built Environment - An Introducing Analysis. Procedia - Social and Behavioral Sciences, 101, 33-43.

Rampullo, A., Licciardello, O., Castiglione, C. (2015). Intrapersonal Factors Effects on Professional Orientation and Environmental Representations. Procedia - Social and Behavioral Sciences, 205, 422-428.

Said, S. Y., Aksah, H., \& Ismail, E. D. (2013). Heritage Conservation and Regeneration of Historic Areas in Malaysia. Procedia-Social and Behavioral Sciences, 105, 418-428.

Sani and Mahasti (2012). Regenerating Regional Identity for Sustainable Tourism Development. Case study :Eslami Island, Iran. Procedia- Social and Behavioral Sciences, 35, 523-530. 
Shirvani, H. (1985). The Urban Design Process. New York. Van Nostrand Reinhold Company.

Page, S. J., Forer, P., \& Lawton, G. R. (1999). Small Business Development and Tourism: Terra Incognita?. Journal of Tourism Management, 20(4), 435-459.

Prajnawrdhi, Tri Anggraini. et al. (2015). Preserving Cultural Heritage of Denpasar: Local Community Perspectives. Procedia - Environmental Sciences, 28, 557 - 566.

Prideaux, B and Copper, M. (2002). Nature Corridors: A Strategy for Regional Tourism Development in Indonesia. ASEAN Journal of Hospitality and Tourism. 1(1). ISSN 14122073.

Ujang, Norsidah and Zakariya, Khalilah. (2015). Place Attachment and the Value of Place in the Life of the Users. Procedia - Social and Behavioral Sciences 168, 373 - 380.

Wang, Suosheng. and Xu, Honggang. (2015). Influence of Place-based Senses of Distinctiveness, Continuity, Self-esteem, and Self-efficacy on Residents' Attitudes toward Tourism. Tourism Management, 47, 241-250. 